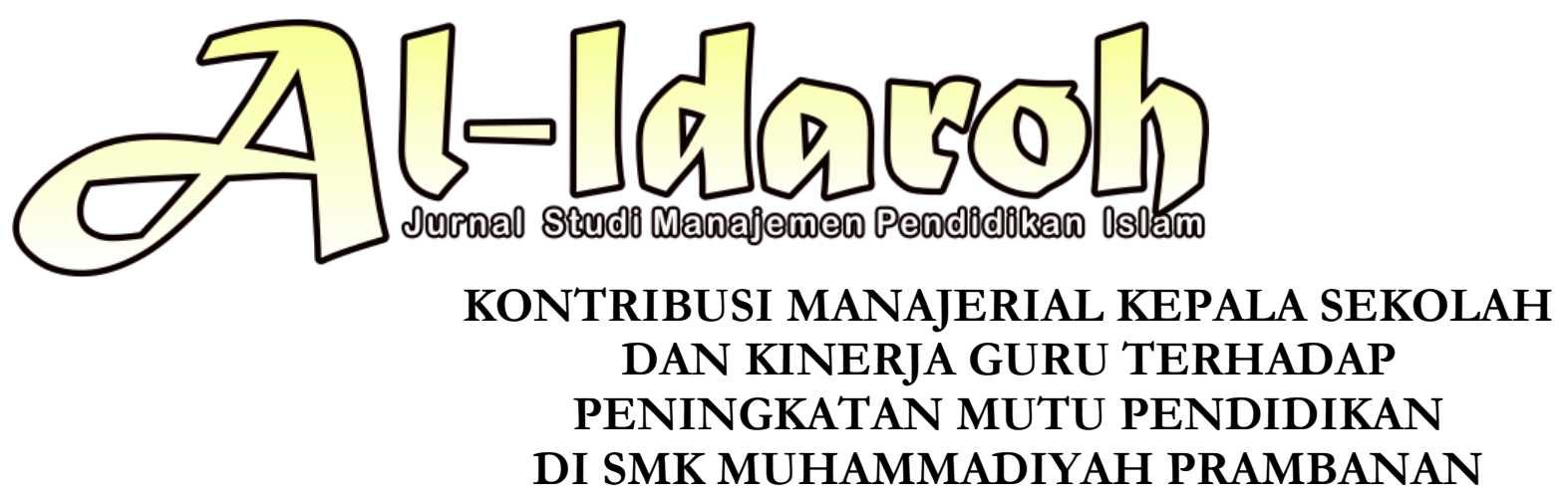

\author{
Erlina Yuliyati \\ Universitas Islam Negeri Sunan Kalijaga Yogyakarta \\ Email: yuliyatierlina@gmail.com \\ Sedya Santosa \\ Universitas Islam Negeri Sunan Kalijaga Yogyakarta \\ Email: sedyasantosa28@gmail.com
}

\begin{abstract}
The quality of education in schools is influenced by many factors, including the contribution of the principal as a leader that determines whether or not the educational goals achieved at the institution he leads, and the performance of teachers who determine the success of the educational process at school. This study aims to determine whether the improvement of school quality is dominated by the principal managerial contributions and teacher performance, or there are other factors that more strongly influence the improvement of the quality of education in SMK Muhammadiyah Prambanan. This research is a quantitative research with a descriptive approach. Data were collected by a questionnaire involving 43 respondents and then analyzed by multiple regression statistical analysis. The quantitative method as an approach in data analysis is to use SPSS version 17.0 tools. The results of the study and data analysis showed that the managerial variable of principals partially had an effect of 0.944 which meant that there was a strong influence of the managerial variables of principals on improving quality, which was $94.4 \%$. Furthermore, teacher performance variables have an effect of 0.937 , which means that $93.7 \%$ of teacher performance contributes or significantly influences the quality of education at SMK Mubammadiyah Prambanan. Simultaneously, the contribution of influence given by the managerial variables of school principals and teacher performance to quality improvement was $96.8 \%$, while another $3.2 \%$ was influenced by other variables in SMK Mubammadiyah Prambanan. This means that, managerial principals and teacher performance contribute greatly to improving the quality of education in SMK Mubammadiyah Prambanan.
\end{abstract}

Keywords: Managerial Principal, Teacher Performance, Education Quality

\title{
Pendahuluan
}

Di era persaingan seperti saat ini khususnya dunia pendidikan, setiap lembaga pendidikan dituntut untuk mampu mempromosikan lembaganya sehingga dapat mempertahankan eksistensinya.. Lembaga pendidikan yang dikelola seadanya akan tertinggal dengan lembaga pendidikan yang dikelola secara professional. Hari ini banyak kita lihat lembaga pendidikan yang telah lama berdiri namun mengalami

Al-Idaroh: Jurnal Studi Manajemen Pendidikan Islam

Volume 4 Nomor 2 September 2020; p-ISSN:2549-8339; e-ISSN: 2579-3683 
penurunan kuantitas maupun kualitasnya sehingga pada akhirnya tutup, akan tetapi ada pula lembaga pendidikan yang mengalami peningkatan setiap tahunnya baik dari jumlah siswa maupun mutu pendidikannya sehingga lembaga pendidikan tersebut mengalami kemajuan yang pesat. Untuk mencapai mutu pendidikan sebagaimana yang diharapkan, tentunya peran kepala sekolah, guru, dan seluruh elemen sangat diperlukan. Kepala sekolah merupakan komponen pendidikan yang berperan penting dalam peningkatan kualitas pendidikan. Kepala sekolah menjadi penanggung jawab atas penyelenggaraan pendidikan, administrasi sekolah, pembinaan terhadap pendidik dan tenaga kependidikan, pendayagunaan serta pemeliharaan sumber daya, serta berperan sebagai supervisor pada sekolah yang dipimpinnya. ${ }^{1}$ Keberhasilan sebuah lembaga sangat dipengaruhi oleh kemampuan manajerial seorang pemimpin sebagai penggerak dalam mencapai tujuan. Kepemimpinan kepala sekolah memiliki peranan penting menjalankan lembaga yang dipimpinnya agar tujuan dapat tercapai sebagaimana diharapkan.

Beberapa karakteristik yang harus dimiliki kepala sekolah sebagai pemimpin, yaitu: a). Energik, yaitu kepala sekolah harus memiliki mental dan fisik yang kuat dalam memimpin, b). Stabilitas emosi, kepala sekolah tidak boleh cepat marah dan berprasangka buruk terhadap anggota, c). Hubungan sosial dan kerampilan sosial, yaitu kepala sekolah harus mengetahui cara bermasyarakat yang baik serta memiliki rasa tanggap terhadap alam sekitar, d). Keterampilan komunikasi, e). Keterampilan mengajar, yaitu kepala sekolah harus mampu mengajar, menjelaskan dan mengembangkan potensi anggota, f). Keterampilan teknis, yaitu kepala sekolah memiliki kecakapan dalam menganalisis, merencanaan, menyusun konsep, mengorganisasi, mendelegasikan wewenang, dan mengambil keputusan. ${ }^{2}$

Tugas manajerial dari seorang kepala sekolah hendaknya memiliki tiga keterampilan utama, yaitu: ${ }^{3}$

1) Kemampuan teknis, yaitu kemampuan seorang kepala sekolah untuk menggunakan prosedur, teknis, dan pengetahuan mengenai bidang tertentu,

${ }^{1}$ E.Mulyasa, Menjadi Kepala Sekolah Profesional (Bandung: Rosda, 2007), 24.

${ }^{2}$ Euis Karwati dan Donni Juni Priansa, Kinerja Dan Profesionalisme Kepala Sekolah (Bandung: Alfabeta, 2013), 173.

${ }^{3}$ Stephen P Robbins, Perilaku Organisasi (Jakarta: Gramedia, 2003), 7. 


\section{Kontribusi Manajerial Kepala Sekolah dan Kinerja Guru Terhadap Peningkatan Mutu Pendidikan di SMK Muhammadiyah Prambanan}

2) Kemampuan manusiawi, kemampuan kepala sekolah dalam membangun kerjasama dengan orang lain, memahami, memotivasi baik sebagai individu ataupun kelompok,

3) Kemampuan konseptual, yang mana kepala sekolah mampu mengkordinasikan serta mengintegrasikan semua aktivitas dan kepentingan organisasi.

Seorang kepala sekolah hendaknya memahami kemampuan manajerial tersebut agar dapat diaktualisasikan kedalam tindakan atau perilaku, agar fungsinya sebagai manajer dapat dilaksanakan dengan efektif. Disamping kepala sekolah dengan kemampuan manajerialnya, guru juga berperan penting dalam meningkatkan mutu pendidikan di sekolah. Oleh karena itu, kepala sekolah perlu memperhatikan faktorfaktor yang dapat meningkatkan kinerja guru. Ada beberapa faktor yang mempengaruhi kinerja seorang guru. Berdasarkan hasil penelitian yang dilakukan oleh Zuhriyah, bahwa faktor yang mempengaruhi kinerja guru adalah kompetensi guru, motivasi kerja, lingkungan kerja, dan kepemimpinan kepala sekolah/madrasah. ${ }^{4}$ Selain Zuhriyah, Barnawi juga menyebutkan ada beberapa faktor yang mempengaruhi kinerja guru, yaitu: gaji, sarana prasarana sekolah/madrasah, lingkungan kerja, dan kepemimpinan kepala sekolah. ${ }^{5}$ Berbeda dengan Sardiman, yang mengungkapkan faktor terpenting bagi seorang guru adalah kedewasaan atau kepribadiannya. ${ }^{6}$ Kinerja berkaitan dengan produktifitas, yang merupakan perbandingan antara keluaran (output) dengan masukan (input). Dalam teori TR. Mitchell dalam Sedarmayanti, untuk mengukur kinerja meliputi beberapa aspek, yaitu: quality of work, promptness, initiative, capability dan communication. ${ }^{\top}$

Keseluruhan faktor tersebut memiliki pengaruh dalam peningkatan kinerja guru yang pada akhirnnya berdampak pada keberhasilan guru dalam meningkatkan kualitas pendidikan di sekkolah. Guru adalah pendidik profesional dengan tugas utama mendidik, mengajar, membimbing, mengarahkan, melatih, menilai, dan mengevaluasi peserta didik pada jalur pendidikan formal, pendidikan dasar dan pendidikan

${ }^{4}$ Siti Zuhriyah, "Faktor-Faktor Yang Mempengaruhi Kinerja Guru SMK Negeri Kelompok Pariwisata Yogyakarta," Jurnal Literasi VI, no. 2 (2015), 214.

${ }^{5}$ Barnawi daan Muh.Arifin, Kinerja Guru Profesional: Instrumen Pembinaan, Peningkatan Dan Penilaian (Yogyakarta: Ar-Ruzz Media, 2012), 43.

'Sardiman A.M, Interaaksi Dan Motivasi Belajar Mengajar (Jakarta: Raja Grafindo Persada, 2007), 132.

${ }^{7}$ Sedarmayanti, Sumber Daya Manusia Dan Produktifitas Kerja (Bandung: Mandor Maju, 2001), 23. 
menengah. ${ }^{8}$ Guru merupakan faktor penting dalam proses pendidikan. Kualitas seorang guru menetukan hasil pendidikan karena guru adalah pihak yang berhubungan langsung dengan peserta didik dalam proses pendidikan di sekolah. Oleh karena itu guru dituntut untuk mampu merespon ilmu pengetahuan dan teknologi yang sedang berkembang sesuai dengan kebutuhan masyarakat dan perkembangan zaman. ${ }^{9}$

Kriteria sekolah bermutu dan memiliki kemampuan untuk berkompetisi, berdasarkan Australia Institute for Teaching and School Leadership (AISTL) dengan standar kepala sekolah/madrasah: (1) mampu meningkatkan prestasi siswa, (2) mempromosikan keunggulan, (3) menciptakan dan mempertahankan keadaan atau meningkatkan kualitas belajar mengajar, (4) mempengaruhi, mengembangkan dan memberikan harapan masyarakat tentang belajar, (5) berkontribusi terhadap perkembangan pendidikan abad-21 ditingkat lokal, nasional ataupun internasional. ${ }^{10}$

Menurut Arcaro, ada tiga indikator pendidikan dikatakan bermutu, yaitu: (1) capaian prestasi akademik berupa nilai ulangan/ujian akhir, karya tulis ilmiyah, dan lomba akademik; (2) prestasi non akademik berupa olahraga, kesenian, lomba non akademik (berupa keterampilan), dan kegiatan ekstrakurikuler lainnya; (3) sikap, seperti kejujuran, kesopanan, disiplin, tanggung jawab, berbudi luhur, serta berjiwa sosial. ${ }^{11}$ Mendukung atas pendapat Arcaro tersebut, Sagala menjelaskan bahwa mutu dari suatu lembaga merupakan suatu gambaran secra menyeluuruh dari jasa pelayanan baik internal maupun eksternal yang menunjukan kemampuannya dalam memberikan kepuasan terhadap kebutuhan yang diharapkan mencakup input, proses dan output pendidikan, yang mana sekolah dikatakan bermutu apabila mampu mencapai prestasi baik akademik maupun non akademik, memiliki nilai kejujuran, kesopanan, memiliki tanggung jawab, serta memiliki kemampuan yang diwujudkan dalam bentuk keterampilan sesuai ilmu yang diterimanya. ${ }^{12}$

${ }^{8}$ Undang-Undang Republik Indonesia No14 Tabun 2005 Tentang Guru Dan Dosen, n.d.

'Sururi, "Manajemen Kepala Madrasah Dalam Meningkatkan Mutu Pendidikan Di Madrasah Ibtidaiyah Muhammadiyah Miri Bulu Polokarto Sukoharjo" (IAIN Surakarta, 2014), http:/ / eprints.iain-surakarta.ac.id/50/1/2014TS0001. pdf.

${ }^{10}$ Handriyani Timor, dkk, "Mutu Sekolah: Antara Kepemimpinan Kepala Sekolah Dan Kinerja Guru," Jurnal Administrasi Pendidikan XXV, no. 1 (2018), 80.

${ }^{11}$ Jarome S. Arcaro, Pendidikan Berbasis Mutu Prinsip-Prinsip Perumusan Dan Tata Langkah Penerapan (Yogyakarta: Pustaka Pelajar, 2006), 13.

${ }^{12}$ Syaiful Sagala, Manajemen Strategik Dalam Peningkatan Mutu Pendidikan (Bandung: Alfabeta, 2013),170. 


\section{Kontribusi Manajerial Kepala Sekolah dan Kinerja Guru Terhadap Peningkatan Mutu Pendidikan di SMK Muhammadiyah Prambanan}

Peningkatan mutu sekolah perlu dilakukan secara berkesinambungan. Dengan demikian, dalam upaya peningkatan mutu sekolah perlu melibatkan lima faktor dominan, yaitu: (1) Kepemimpinan kepala sekolah, (2) Siswa, (3) Guru, (4) Kurikulum, (5) Jaringan kerjasama. ${ }^{13}$ Penelitian berjudul "Kinerja Manajerial Kepala Sekolah, Kinerja Mengajar Guru dan Mutu Sekolah Dasar" yang disusun oleh Irma Anggraeni dkk yang mana penelitian tersebut dilatar belakangi oleh adanya kesenjangan empiris dengan teori yang berlaku. namun demikian, hasil penelitian menunjukan bahwa antara kinerja kepala sekolah dan kinerja guru memiliki pengaruh yang signifikan terhadap mutu sekolah. Berdasarkan hasil temuan yang dilakukan dalam penelitian ini, indikator prestasi siswa berada diangka yang paling rendah, sehingga diperlukan peran aktif kepala sekolah untuk optimalisasi peran guru dalam pembelajaran karena prestasi siswa lebih dekat dengan peranan guru. ${ }^{14}$

Penelitian juga dilakukan Yeni Setiyawati dengan judul "Pengaruh Kemampuan Manajerial Kepala Sekolah dan Supervisi Akademik Pengawas terhadap Kinerja Mengajar Guru di SMAN Se-Kota Banjar'. Penelitian ini dilatar belakangi dengan posisi guru yang merupakan salah satu penentu tinggi rendahnya mutu pendidikan. hasil penelitian menunjukan, kemampuan manajerial kepala sekolah dan supervisi akademik pengawas berpengaruh positif terhadap kinerja mengajar guru sebesar 46,8 \%, sedangkan 54,2 \% dipengaruhi oleh variabel lain. Hal tersebut berarti bahwa, semakin tinggi kinerja manajerial kepala sekolah dan efektifnya supervisi akademik pengawas, maka kinerja mengajar guru juga akan semakin meningkat. ${ }^{15}$

Penelitian Muhamad Kosim, dengan judul "Pengarub Kepemimpinan Kepala Sekolah dan Kinerja Guru untuk Mewujudkan Mutu Pembelajaran". Dalam penelitian tersebut metode analisis yang digunakan dalam penelitian adalah causal efektual, yaitu dengan meninjau hubungan rasional yang menunjukan hubungan sebab akibat antara kepemimpinan kepala sekolah dan kinerja guru dengan mutu pembelajaran. Dengan demikian dari penelitian ini diperoleh hasil bahwa untuk meningkatkan mutu

\footnotetext{
${ }^{13}$ Sudarman Danim, Motivasi Kepemimpinan Dan Efektifitas Kelompok (Jakarta: Rineka Cipta, 2004), 56. ${ }^{14}$ Taufani C. Kurniatun Irma Anggraeni, Aan Komariah, "Kinerja Manajerial Kepala Sekolah, Kinerja Mengajar Guru Dan Mutu Sekolah Dasar," Jurnal Administrasi Pendidikan XXIII, no. 2 (2016), 134-139. ${ }^{15}$ Yeni Setiyawati, "Pengaruh Kemampuan Manajerial Kepala Sekolah Dan Supervisi Akademik Pengawas Terhadap Kinerja Mengajar Guru (Studi Pada SMAN Se-Kota Banjar)," Jurnal Ilmiah Edukasi 4, no. 3 (2016), 289-292.
} 
pembelajaran secara efektif dan efisien dapat dilakukan dengan cara meningkatkan kepemimpinan kepala sekolah dan kinerja guru. ${ }^{16}$

Demikian juga dengan Asmawati yang melakukan penelitian dengan judul “ Pengaruh Kinerja Guru terhadap Hasil Belajar Siswa Sekolah Dasar di Kecamatan Larompong Kabupaten Luwu". Hasil penelitian yang dilakukan tersebut menunjukan: (1) kinerja guru mempengaruhi peningkatan belajar siswa, (2) semakin besar usaha guru dalam perencaan, pelaksanaan, serta evaluasi pembelajaran, maka semakin besar peluang guru untuk meningkatkan skor hasil belajar siswa, (3) penngalaman mengajar guru berkontribusi dalam meningkatkan hasil belajar siswa. ${ }^{17}$

Peningkatan mutu pendidikan secara nasional yang terpusat pada penigkatan mutu pendidikan di sekolah merupakan suatu proses yang tidak instan, akan tetapi membutuhkan proses panjang dan dilakuan secara terus menerus, bertahap, terukur serta memiliki arah yang jelas.SMK Muhammadiyah Prambanan merupakan sekolah yang dikelola oleh yayasan. SMK Muhammadiyah Prambanan tergolong sekolah yang memiliki keunggulan kompetitif. Hal tersebut terlihat dari guru dan siswa yang dimiliki sekolah tersebut, serta prestasi yang sudah dicapai oleh sekolah. Disisi lain, berdasarkan observasi awal yang dilakukan peneliti, SMK Muhammaddiyah prambanan mencapai akreditasi A serta telah mendapat sertifikat ISO, disamping jumlah siswa yang semakin meningkat hingga saat ini mencapai lebih dari 800 siswa. Ketercapaian tersebut tentunya tidak terlepas dari kerampilan kepala sekolah, kinerja guru, dan seluruh elemen yang terlibat seperti pengurus yayasan, komite, peserta didik dan sebagainya. SMK Muhammadiyah Prambanan merupakan salah satu sekolah yang sejak awal berdiri sampai hari ini tetap berupaya untuk merekrut serta melakukan pembinaan guru yang akan menjadi tenaga pendidik yang bertugas dengan baik dan profeional sebagai upaya dalam peningkatan mutu SMK Muhammadiyah Prambanan.

\footnotetext{
${ }^{16}$ MuhamadKosim, "Pengaruh Kepemimpinan Kepala Sekolah Terhadap Kinerja Guru Untuk Mewujudkan Mutu Pembelajaran," Jurnal Khazanah Akademia 1, no. 1 (2017), 30.

${ }^{17}$ Asmawati, "Pengaruh Kinerja Guru Terhadap Hasil Belajar Siswa Sekolah Dasar Di Kecamatan Larompong Kabupaten Luwu," Pedagogy 2, no. 1 (2017), 44.
} 


\section{Kontribusi Manajerial Kepala Sekolah dan Kinerja Guru Terhadap \\ Peningkatan Mutu Pendidikan di SMK Muhammadiyah Prambanan}

\section{Metode Penelitian}

Penelitian ini dilaksanakan di SMK Muhammadiyah Prambanan beralamat di Jl. Piyungan, Bokoharjo, Kecamatan Prambanan, Kabupaten Sleman, Daerah Istimewa Yogyakarta. Penelitian ini merupakan penelitian kuantitatif dengan pendekatan deskriptif. Pengumpulan data menggunakan instrument penelitian, analisis datanya bersifat kuantitatif/statistic, yang bertujuan untuk menguji hipotesis ${ }^{18}$. Dalam penelitian ini menggunakan metode analisis regresi linier berganda dengan program SPSS versi 0.17. Populasi dalam penelitian adalah sejumlah guru SMK Muhammadiyah Prambanan yang berjumlah 89 dan sampel yang digunakan 43 orang. Untuk memperoleh data, penulis melakukan penyebaran kuesioner dengan masingmasing 4 option jawaban. Selanjutnya yang menjadi variabel dalam penelitian ini meliputi manajerial kepala sekolah $\left(\mathrm{x}_{1}\right)$, kinerja guru $\left(\mathrm{x}_{2}\right)$, dan peningkatan mutu pendidikan (Y). Teknik analisis data, penulis menggunakan bantuan program SPSS untuk mengetahui besarnya kontribusi variabel manajerial kepala sekolah $\left(\mathrm{x}_{1}\right)$ dan variabel kinerja guru $\left(\mathrm{x}_{2}\right)$ terhadap peingkatan mutu pendidikan $\left(\mathrm{x}_{3}\right)$.

\section{Hasil Penelitian dan Pembahasan}

1. Manajerial Kepala Sekolah

Responden SMK Muhammadiyah Prambanan memberikan jawaban terhadap kuesioner yang disebarkan oleh peneliti sebanyak 30 butir Item soal yang didalamnya mencakup indikator kemampuan konsep, kemampuan manusiawi/sosial, dan kemampuan teknik diperoleh skor minimum 84 dan maksimum 109, dengan skor rata-ratanya 93,19 dan standar deviasi (s) 5,611. Secara umum, manajerial kepala sekolah SMK Muhammaddiyah Prambanan berdasarkan pandangan responden cukup sesuai dalam memberikan kontribusi dalam peningkaatan mutu, sebagaimana dapat diketahui pada tabel berikut:

${ }^{18}$ Sugiyono, Metode Penelitian Kuantitatif (Bandung: Alfabeta, 2018), 15. 
Tabel 1.Pendapat responden mengenai manajerial kepala sekolah SMK

Muhammadiyah Prambanan

\begin{tabular}{|llccc|}
\hline $\mathbf{N o}$ & Kriteria & Skor & Frekuensi & $\%$ \\
\hline $\mathbf{1}$ & Sangat sesuai & $109-102$ & 4 & $9,30 \%$ \\
\hline $\mathbf{2}$ & Sesuai & $101-96$ & 6 & $13,95 \%$ \\
\hline $\mathbf{3}$ & Cukup sesuai & $95-90$ & 23 & $53,4 \%$ \\
\hline $\mathbf{4}$ & Tidak sesuai & $89-84$ & 10 & $23,2 \%$ \\
\hline & N & - & 43 & \\
\hline
\end{tabular}

Dengan tabel tersebut dapat diketahui bahwa responden memberikan argumentasinya mengenai manajerial kepala sekolah sangat sesuai sebanyak 9,30\%, yang berpendapat sesuai sebanyak 13,95\%, yang berpendapat cukup sesuai sebanyak 53,4\%, dan yang berpendapat tidak sesuai 23,2\%. Dengan demikian, maka dapat disimpulkan bahwa secara umum responden berpendapat bahwa kemampuan manajerial kepala sekolah cukup sesuai membawa lembaga untuk mencapai mutu unggul sesuai yang diharapkan.

\section{Kinerja Guru}

Kuesioner kinerja guru SMK Muhammadiyah Prambanan yang disebarkan ada 20 Item soal dengan beberapa indikator yang mencakup quality of work, promptness, initiative, capability, dan communication. Dari variabel kinerja guru diperoleh skor minimum 47, maksimum 66, dengan skor rata-ratanya 54,16, dan standar deviasinya 4, 231. Dilihat dari jawaban yang diberikan responden menunjukan secara umum sering memberikan kontribusi, sebagaimana terangkum dalam tabel berikut:

Tabel 2.Pendapat responden mengenai kinerja guru di SMK Muhammadiyah Prambanan

\begin{tabular}{|llccl|}
\hline No & Kriteria & Skor & Frekuensi & $\%$ \\
\hline $\mathbf{1}$ & Selalu & $66-62$ & 4 & $9,30 \%$ \\
\hline $\mathbf{2}$ & Sering & $61-57$ & 4 & $9,30 \%$ \\
\hline $\mathbf{3}$ & Kadang-kadang & $56-52$ & 23 & $53,4 \%$ \\
\hline $\mathbf{4}$ & Tidak Pernah & $51-47$ & 12 & $27,9 \%$ \\
\hline & N & & 43 & \\
\hline
\end{tabular}

Tabel tersebut menunjukan bahwa responden berpendapat guru selalu melakukan kinerja dengan baik sebanyak 9,30\%, sering melakukan kinerja dengan 


\section{Kontribusi Manajerial Kepala Sekolah dan Kinerja Guru Terhadap Peningkatan Mutu Pendidikan di SMK Muhammadiyah Prambanan}

baik 9,30\%, kadang-kadang 53,4\%, dan tidak pernah sebanyak 27,9\%. Dengan demikian jika dilihat hasil analisis terhadap kuesioner yang disebarkan, maka kinerja guru kadang-kadang memberikan kontribusi sebesar 53,4\% dalam peningkatan mutu pendidikan.

3. Peningkatan Mutu Pendidikan di Sekolah

Jawaban yang diberikan oleh responden dalam menjawab Item soal angket sebanyak 20 butir soal tentang peningkatan mutu yang didalamnya terdapat beberapa indikator berupa prestasi akademik, prestasi non akademik, dan sikap/perilaku, yang diperoleh skor minimum 42, skor maksimum 57, dengan skor rata-rata 49,95 dan standar deviasinya 3,251. Pendapat responden tentang peningkatan mutu pendidikan di SMK Muhammadiyah Prambanan sebagaimana terangkum dalam tabel berikut:

Tabel 3. Peningkatan mutu Pendidikan di SMK Muhammadiyah Prambanan

\begin{tabular}{|llccc|}
\hline No & Kriteria & Skor & Frekuensi & \multicolumn{1}{l}{ \% } \\
\hline $\mathbf{1}$ & Selalu & $57-54$ & 4 & $9,30 \%$ \\
\hline $\mathbf{2}$ & Sering & $53-50$ & 21 & $48,83 \%$ \\
\hline $\mathbf{3}$ & Kadang-kadang & $49-46$ & 14 & $32,55 \%$ \\
\hline $\mathbf{4}$ & Tidak Pernah & $45-42$ & 4 & $9,30 \%$ \\
\hline
\end{tabular}

Berdasarkan tabel rangkuman diatas, maka dapat dideskripsikan bahwa responden berpendapat, SMK Muhammadiyah Prambanan selalu melakukan peningkatan sebanyak 9,30\%, sering melakukan peningkatan mutu sebanyak 48,83\%, kadang-kadang dilakukan peningkatan mutu sebanyak 32,55\%, dan tidak pernah sebanyak 9,30\%. Dengan demikian dapat disimpulkan bahwa pendapat responden secara umum berpendapat SMK Muhammadiyah Prambanan sering melakukan peningkatan mutu pendidikan untuk mencapai target yang telak ditetapkan oleh sekolah. 


\section{Analisis Pengaruh Antar Variabel}

1. Analisis Kontribusi Variabel Manajerial Kepala Sekolah ( $\left.\mathbf{X}_{1}\right)$ Terhadap Peningkatan Mutu Pendidikan (Y)

Perhitungan data dengan bantuan program SPSS versi 17.0 diketahui besarnya pengaruh manajerial kepala sekolah $\left(\mathrm{X}_{1}\right)$ terhadap peningkatan mutu $(\mathrm{Y})$, diperoleh besarnya nilai F. besarnya nilai F dalam tabel Anova adalah 688,784 dan signifikansi sebesar 0,000. 0,000 dalam tabel Anova lebih kecil dari 0,05 sehingga dengan demikian Ho ditolak dan Ha diterima. Sebagaimana pegambilan keputusan dalam regresi (pengaruh), jika Ho ditolak maka terjadi pengaruh. Besarnya persentase pengaruh variabel manajerial kepala sekolah terhadap peningkatan mutu adalah sebesar 94,4\% dan selebihnya dipengaruhi oleh variabel lain. Dengan demikian, manajerial kepala sekolah memiliki pengaruh terhadap peningkatan mutu pendidikan di SMK Muhammadiyah Prambanan.

2. Analisis Kontribusi Variabel Kinerja Guru $\left(X_{2}\right)$ Terhadap Peningkatan Mutu Pendidikan $(\mathrm{Y})$

Hipotesis kedua ini menjawab pengaruh kinerja guru terhadap peningkatan mutu di SMK Muhammadiyah Prambanan, diperoleh data dengan nilai F sebesar 613,392. Besarnya nilai F dalam tabel Anova 613,392 dan signifikansi sebesar 0,000. 0,000 dalam tabel Anova menunjukan lebih kecil dari 0,05 berarti bahwa Ho ditolak dan $\mathrm{Ha}$ diterima. Sebagaimana pegambilan keputusan dalam regresi (pengaruh), jika Ho ditolak maka terjadi pengaruh. Besarnya persentase pengaruh variabel kinerja guru terhadap peningkatan mutu adalah sebesar 93,7\% dan selebihnya dipengaruhi oleh variabel lain, sehingga jelaslah bawa kinerja guru memiliki kontribusi besar terhadap peningkatan mutu pendidikan di SMK Muhammadiyah Prambanan.

3. Analisis Kontribusi Variabel Manajerial Kepala Sekolah $\left(\mathrm{X}_{1}\right)$ dan Kinerja Guru $\left(\mathrm{X}_{2}\right)$ Terhadap Peningkatan Mutu Pendidikan (Y)

Dalam menganalisis permasalahan dalam penelitian ini, maka peneliti menggunakan analisis regresi berganda, dengan hipotesis sebagai berikut:

$\mathrm{H}_{\mathrm{a}} \quad$ : adanya pengaruh yang signifikan antara manajerial kepala sekolah dan kinerja guru terhadap peningkatan mutu pendidikan di SMK Muhammadiyah Prambanan. 


\section{Kontribusi Manajerial Kepala Sekolah dan Kinerja Guru Terhadap \\ Peningkatan Mutu Pendidikan di SMK Muhammadiyah Prambanan}

$\mathrm{H}_{\mathrm{o}} \quad$ : tidak adanya pengaruh yang signifikan antara manajerial kepala sekolah dan kinerja guru terhadap peningkatan mutu pendidikan di SMK Muhammadiyah Prambanan.

Bila dalam statistic dapat digambarkan sebagai berikut:

$\mathrm{H}_{\mathrm{a}} \quad \neq 0$

$\mathrm{H}_{\mathrm{o}} \quad=0$

Program SPSS versi 17.0 digunakan untuk menguji kontribusi pengaruh $\mathrm{X}_{1}$ dan $\mathrm{X}_{2}$ terhadap $\mathrm{Y}$. Setelah melakukan analisis korelasi berganda, selanjutnya dimasukan kedalam persamaan regresi berganda, sebagaimana rumus berikut:

$$
\mathrm{Y}=\mathrm{a}+\mathrm{X}_{1}+\mathrm{X}_{2}
$$

Bila dimasukan kedalam rumus persamaan regresi tersebut, maka diperoleh:

$$
\mathrm{Y}=1,382+0,374 \mathrm{X}_{1}+0,252 \mathrm{X}_{2}
$$

Persamaan regresi tersebut dapat dijadikan sebagai alat prediksi dan estimasi. Koefisien regresi dan signifikansinya dapat diketahui dengan melihat besarnya uji t. koefisien uji $\mathrm{t}$ sebagai dasar dalam menetapkan signifikansi diperlukan t tabel (terlampir), untuk memudahkan dalam interpretasi. Besarnya pengaruh manajerial kepala sekolah dan kinerja guru terhadap peningkatan mutu adalah 94,6 \%. Dengan demikian dapat disimpulkan bahwa $\mathrm{x}_{1}$ dan $\mathrm{x}_{2}$ memberikan kontribusi besar terhadap Y di SMK Muhammadiyah Prambanan.

\section{Pembahasan Hasil Penelitian}

Keberhasilan lembaga pendidikan dalam hal ini tercapai tidaknya tujuan sekolah sangat ditentukan oleh sumber daya manusia didalamnya. Kepala sekolah berperan penting dalam memimpin lembaganya agar tujuan pendidikan tercapai sebagaimana diharapkan. Hal tersebut juga diungkapkan oleh Mulyasa, bahwa kepala sekolah bertanggung jawab atas penyelenggaraan pendidikan pada sekolah yang dipimpinnya.

Untuk mencapai tujuan yang diharapkan, maka kepala sekolah sebagai pemimpin pendidikan harus memiliki keterampilan manajerial. Keterampilan manajerial yang dimaksud adalah kemampuan kepala sekolah dalam mengelola, mengorganisir serta mendayagunakan seluruh potensi yang dimiliki demi tercapainya 
tujuan sekolah. Oleh karena itu, keterampilan manajerial kepala sekolah perlu ditingkatkan. Berbagai indikator yang harus dimiliki oleh kepala sekolah yang memiliki cita-cita untuk mengembangkan dan memiliki daya saing, yaitu sebagaimana teori yang ditawarkan oleh Robins, sebagaimana dapat digambarkan dalam bagan berikut:

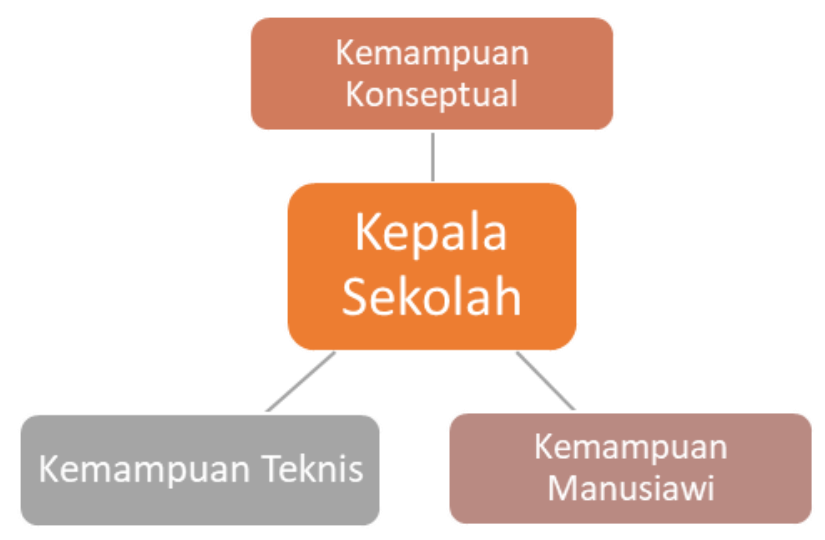

Gambar 1. Kemampuan Manajerial

1. Kemampuan teknis

Merupakan kemampuan kepala sekolah mengenai prosedur, teknis, dan pengetahuan mengenai bidang tertentu. Adapun kemampuan teknis kepala sekolah meliputi kemampuan kepala sekolah dalam melaksanakan pembinaan dan bimbingan terhadap pendidik dan tenaga kependidikan, melaksanakan supervise/pengawasan terhadap program ataupun praktik mengajar guru di kelas, mengevaluasi program pengajaran guru.

2. Kemampuan konseptual

Keterampilan lain yang harus ada dalam diri seorang kepala sekolah adalah kemampuan konseptual. Kepala sekolah dituntut untuk dapat membuat perencanaan program, merumuskan visi-misi sekolah, mengidentifikasi persmasalahan yang timbul serta membuat alternative pemecahan masalah, melakukan pengembangan SDM (pendidik dan tenaga kependidikan), menyusun rencana kerja dan anggaran sekolah, dan responsive terhadap perubahan dan perkembangan sehingga mampu meningkatkan daya saing. 


\section{Kontribusi Manajerial Kepala Sekolah dan Kinerja Guru Terhadap Peningkatan Mutu Pendidikan di SMK Muhammadiyah Prambanan}

3. Kemampuan manusiawi

Kemampuan mmanusiawi atau dikenal dengan kemampuan sosial merupakan indikator yang sangat penting dalam diri kepala sekolah.hal tersebut berkaitan dengan input, proses dan output sekolah. adapun keterampilan soasial kepala sekolah diantaranya adalah menjalin hubungan dan kerjasama yang baik dengan masyarakat sebagai pengguna lulusan, membangun teamwork, memperhatikan kesejahteraan guru maupun tenaga kependidikan, sampai pada pemberian reward kepada pendidik dan tenaga kependidikan yang berprestasi.

Kepala sekolah merupakan garda terdepan dalam upaya peningkatan mutu pendidikan di lembaga yang dipimpinnya.Baik tidaknya kualitas merupakan akibat dari manajemen kepala sekolah.SMK Muhammadiyah Prambanan termasuk sekolah tertua di Prambanan yang telah lama berdiri, dan merupakan sekolah unggul.Di bawah kepemimpinan Drs. Iskak Riyanto, SMK Muhammadiyah Prambanan banyak mengalami peningkatan.Hal tersebut dapat dilihat dari banyaknya jumlah siswa yang mencapai lebih dari delapan ratus orang siswa, disamping menjadi sekolah dengan peringkat pertama tingkat SMK di Kabupaten Sleman, Yogyakarta. ${ }^{19}$

Prestasi tersebut tentunya tidak lepas dari kerja keras kepala sekolah dan kinerja guru yang secara bersama-sama bekerja dan bekerja sama untuk mengembangkan sekolah dan meningkatkan mutu pendidikan. Peran guru sama pentingnya dalam meningkatkan mutu. Guru sebagai ujung tombak kemajuan pendidikan. berkualitas atau tidaknya lembaga pendidikan, salah satu indikatornya adalah kinerja guru dalam mengelola pembelajaran sehingga menghasilkan output yang berkualitas. Kualitas kinerja guru dapat dilihat dari kualitas kerjanya, ketepatan dalam mengelola pembelajaran, berkomunikasi dengan baik, inisiatif yang tinggi, atau dengan kata lain knowledge management yang tepat. Lembaga pendidikan berkualitas atau bermutu manakala mampu bersaing dengan lembaga pendidikan lainnya.

${ }^{19}$ Erlina Yuliyati, "Pengembangan Sumber Daya Manusia Berbasis Total Quality Management Di SMK Muhammadiyah Prambanan," Al-Tanzim 4, no. 1 (2020). 
Berdasarkan hasil penelitian di SMK Muhammadiyah Prambanan dan uji hipotesis menunjukan adanya kontribusi manajerial kepala sekolah dan kinerja guru terhadap peningkatan mutu pendidikan di sekolah tersebut.

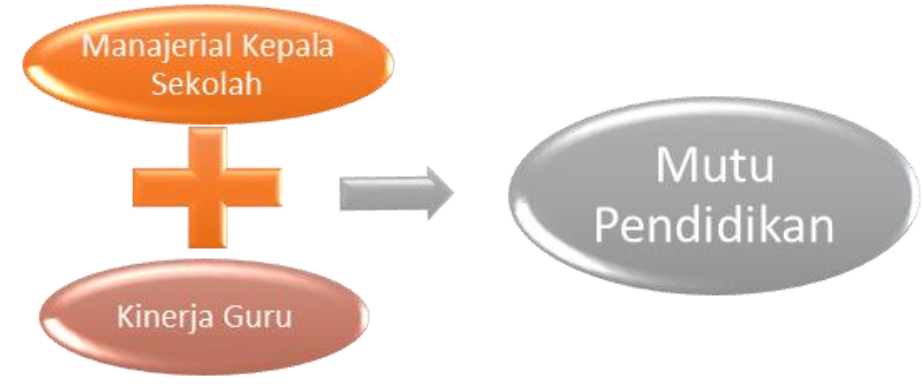

Gambar 2. Kontribusi variable X terhadap Y

Hasil penelitian serta analisis data yang telah dilakukan dapat diketahui bahwa berdasarkan pengujian hipotesis menyatakan, bahwa manajerial kepala sekolah $\left(\mathrm{x}_{1}\right)$ dan kinerja guru $\left(\mathrm{x}_{2}\right)$ memiliki kontribusi yang signifikan terhadap peningkatan mutu sekolah $(\mathrm{Y})$ telah terbukti kebenarannya, sehingga dapat ditarik kesimpulan bahwa kepala sekolah dan kinerja guru secara simultan berkontribusi terhadap peningkatan mutu pendidikan di SMK Muhammadiyah Prambanan, dan penelitian ini mendukung hasil penelitian yang dilakukan para peneliti sebelumnya.

Berdasarkan pada analisis $\mathrm{R}$ square nilai sebesar 0,968, yang berarti kontribusi manajerial kepala sekolah dan kinerja guru terhadap peningkatan mutu pendidikan di SMK Muhammadiyah Prambanan 0,968 atau 96,8 \%, atau dapat diartikan dengan peningkatan mutu di SMK Muhammadiyah Prambanan 96,8 \% dipengaruhi oleh manajerial kepala sekolah dan kinerja guru di sekolah tersebut, sedangkan 3,2\% lagi dipengaruhi oleh variabel lain yang tidak masuk dalam cakupan penelitian.

Dengan demikian, jelaslah bahwa baik kepala sekolah maupun guru merupakan faktor penting dalam peningkatan mutu pendidikan di sekolah yang akan berdampak pada kualitas pendidikan secara nasional. Penilaian terhadap kepala sekolah dalam penelitian ini ditinjau dari keterampilan manajerial yang dimilikinya, seperti kemampuan konseptual, kemampuan sosial dan kemampuan teknik dalam mengelola lembaga pendidikan yang dipimpinnya. Faktor lain yang ikut berkontribusi terhadap peningkatan mutu pendidikan di sekolah adalah 


\section{Kontribusi Manajerial Kepala Sekolah dan Kinerja Guru Terhadap Peningkatan Mutu Pendidikan di SMK Muhammadiyah Prambanan}

kinerja guru. Kontribusi kinerja guru dalam penelitian ini adalah kualitas pekerjaan yang dilakukan (Quality of work), inisiatif dalam mengelola pembelajaran, kemampuan yang dimiliki, serta mampu berkomunikasi dengan baik.

\section{Kesimpulan}

Berdasarkan hasil penelitian dan analisis data yang telah dipaparkan pada bab sebelumnya, maka dapat disimpulkan: Pertaman, Secara parsial bahwa hasil penelitian menunjukan variabel manajerial kepala sekolah berpengaruh sebesar 0,944 yang berarti bahwa adanya pengaruh yang kuat dari variabel manajerial kepala sekolah terhadap peningkatan mutu, yaitu sebesar 94,4 \%. Kedua, Hasil penelitian menunjukan variabel kinerja guru berpengaruh sebesar 0,937 yang berarti bahwa sebesar 93,7\% kinerja guru berkontribusi atau berpengaruh signifikan terhadap peningkatan mutu pendidikan di SMK Muhammadiyah Prambanan. Ketiga, Manajerial dan kinerja guru secara simultan berpengaruh terhadap peningkatan mutu pendiidikan di SMK Muhammadiyah Prambanan. Kontribusi pengaruh yang diberikan oleh variabel manajerial kepala sekolah dan kinerja guru terhadap peningkatan mutu adalah sebesar 96,8 \%, sedangkan 3,2\% lagi dipengaruhi oleh variabel lain di SMK Muhammadiyah Prambanan.

\section{Daftar Rujukan}

A.M, Sardiman. Interaaksi Dan Motivasi Belajar Mengajar. Jakarta: Raja Grafindo Persada, 2007.

Arcaro, Jarome S. Pendidikan Berbasis Mutu Prinsip-Prinsip Perumusan Dan Tata Langkah Penerapan. Yogyakarta: Pustaka Pelajar, 2006.

Danim, Sudarman. Motivasi Kepemimpinan Dan Efektifitas Kelompok. Jakarta: Rineka Cipta, 2004.

E.Mulyasa. Menjadi Kepala Sekolah Profesional. Bandung: Rosda, 2007.

Muh.Arifin, Barnawi dan. Kinerja Guru Profesional: Instrumen Pembinaan, Peningkatan Dan Penilaian. Yogyakarta: Ar-Ruzz Media, 2012.

Priansa, Euis Karwati dan Donni Juni. Kinerja Dan Profesionalisme Kepala Sekolah. Bandung: Alfabeta, 2013. 
Sagala, Syaiful. Manajemen Strategik Dalam Peningkatan Mutu Pendidikan. Bandung: Alfabeta, 2013.

Sedarmayanti. Sumber Daya Manusia Dan Produktifitas Kerja. Bandung: Mandor Maju, 2001.

Stephen P Robbins. Perilaku Organisasi. Jakarta: Gramedia, 2003.

Sugiyono. Metode Penelitian Kuantitatif. Bandung: Alfabeta, 2018.

Undang-Undang Republik Indonesia No14 Tabun 2005 Tentang Guru Dan Dosen, n.d.

Asmawati. "Pengaruh Kinerja Guru Terhadap Hasil Belajar Siswa Sekolah Dasar Di Kecamatan Larompong Kabupaten Luwu.” Pedagogy Vol. 2, No. 1 (2017).

Erlina Yuliyati. "Pengembangan Sumber Daya Manusia Berbasis Total Quality Management Di SMK Muhammadiyah Prambanan.” Al-Tanzim Vol. 4, No. 1 (2020).

Handriyani Timor, Dkk. "Mutu Sekolah: Antara Kepemimpinan Kepala Sekolah Dan Kinerja Guru.” Jurnal Administrasi Pendidikan Vol. XXV, No. 1 (2018).

Irma Anggraeni, Aan Komariah, Taufani C. Kurniatun. "Kinerja Manajerial Kepala Sekolah, Kinerja Mengajar Guru Dan Mutu Sekolah Dasar." Jurnal Administrasi Pendidikan Vol. XXIII, No. 2 (2016).

Kosim, Muhamad. "Pengaruh Kepemimpinan Kepala Sekolah Terhadap Kinerja Guru Untuk Mewujudkan Mutu Pembelajaran." Jurnal Khazanah Akademia Vol. 1, No. 1 (2017).

Setiyawati, Yeni. "Pengaruh Kemampuan Manajerial Kepala Sekolah Dan Supervisi Akademik Pengawas Terhadap Kinerja Mengajar Guru (Studi Pada SMAN Se-Kota Banjar).” Jurnal Ilmiah Edukasi Vol. 4, no. 3 (2016).

Sururi. "Manajemen Kepala Madrasah Dalam Meningkatkan Mutu Pendidikan Di Madrasah Ibtidaiyah Muhammadiyah Miri Bulu Polokarto Sukoharjo." IAIN Surakarta, 2014. http://eprints.iain-surakarta.ac.id/50/1/2014TS0001.pdf.

Zuhriyah, Siti. "Faktor-Faktor Yang Mempengaruhi Kinerja Guru SMK Negeri Kelompok Pariwisata Yogyakarta.” Jurnal Literasi VI, no. 2 (2015). 